\title{
DICAM DUMTAXAT QUOD EST HISTORICON: VARRO AND/ON THE PAST
}

\author{
GIORGIO PIRAS
}

\begin{abstract}
Varro's approach to his subjects is usually systematic and synchronic, but there are frequent diachronic digressions and observations on time and the past, often divided into three stages (remote past, near past, and present). I discuss Rust. 2.1, with a progressive concept of three successive stages in human history from Dicaearchus, and a fragment from Censorinus, where Varro distinguishes tria discrimina temporum. A significant affinity emerges between etymological research and the study of origins: both involve the study of antiquitas or the origo, and both use the genealogical-reconstructive method. The same image of gradus descendere indicates the sequence of logical and chronological steps in describing human history (Rust. 2.1.3-5) and etymological research (Ling. 5.7-9). Varro is fully aware of the difficulties in reconstructing the ancient past and the origins of language, because uncertainty is a characteristic of the origo of human history and of words.
\end{abstract}

Keywords: Varro, De lingua Latina; Res rusticae; etymology; antiquarian; history; Dicaearchus; Censorinus; antiquitas; vetustas

In one of his famous contributions on ancient history Arnaldo Momigliano underlined Varro's role as founder of antiquarian studies. He insisted in particular on the systematic aspect of Varro's approach to all aspects of life, specifically of human society and Roman affairs as dealt with in the Antiquitates. ${ }^{1}$ Varro usually uses synchronic schemes based on dimensional categories (e.g., homines, loca, tempora, res), to organize his potentially unwieldy subject matter, whether farming or the Latin language or the history of the Roman people; but this arrangement does not preclude diachronic organization of the material and of specific subjects. The present contribution will mainly examine the structures of Varro's Antiquitates, De lingua Latina, Res rusticae, and De gente populi Romani. We shall explore how Varro interweaves a mainly synchronic approach with diachronic observations and digressions. Varro is realistic about the obscurity of the earliest phases of his subject matter, but he nonetheless defends an inductive-reconstructive method whereby the antiquarian can still work backwards from the present. Varro thus reveals his interest in and attitude to the past.

The general organization of the Antiquitates follows a comprehensive model that was dear to Varro, comprising the four categories: locus, corpus, tempus, and actio. ${ }^{2}$ The four categories are used both in the Antiquitates humanae and in the divinae (cf. August. De civ. D. 6.3). The Res humanae is in fact devoted to the treatment of homines, loca, tempora, res, and the $A D$ to cults, broken down into homines, loca, tempora, res (in this case the res are the sacra). The categories locus, corpus, tempus, and actio - which evidently appeared to Varro to be particularly suited to the organization of his treatises - are also to be found in other Varronian works or divisions of works. This quadripartite grouping is also that of the words whose etymologies are provided in books 5-7 of De lingua Latina. Book 5 of the $L L$

\footnotetext{
${ }^{1}$ Cf. Momigliano 1950.

${ }^{2}$ On this quadripartite scheme see especially Piras 1998: 25-56; Blank 2008: 59-61.
} 
concerns the etymologies of words involving locus and corpus, book 6 tempus and actio, and book 7 the etymologies of words created and employed by the poets, still within the scheme of the four categories. It may be noted that this quadripartite division is an abstract model based not in fact on the linguistic characteristics of the words Varro examines, but rather on the objects which they represent (Ling. 5.13, quod quattuor genera prima rerum, totidem verborum).

It is worth noting that, according to Cicero, this fourfold model used to inform more primitive works of history, works that were not rhetorically elaborate, and which the earliest Roman historians (Cato, Pictor, Piso) created from the annales maximi (De or. 2.52-53): 'history began as a mere compilation of annals (annalium confectio)... A similar style of writing has been adopted by many who, without any rhetorical ornament (sine ullis ornamentis), have left behind them bare records of dates, personalities, places, and events (monumenta solum temporum hominum (= corpora) locorum gestarumque rerum (= res) reliquerunt). ${ }^{3}$ Varro thus uses in his works an arrangement of material that Cicero considers specific to annalistic and early (indeed primitive) Roman historiography before there was proper historical research. He chose for his own works an approach that was felt to be nonhistorical, or at least one that was not currently in use. This scheme in Varro became primary rather than a subdivision within the typical chronological arrangement of annals.

The overall arrangement of the De lingua Latina corresponds to the phenomenon of language itself. The work is divided into three parts (like language itself, Ling. 8.1): the first devoted to the impositio verborum, in other words, to etymology, the second to morphology, and the third to syntax. ${ }^{4}$ Etymology can often provide the starting point for a diachronic view of individual phenomena, even if it is limited to the history of specific individual words, for which Varro endeavours to provide a reconstruction of their original forms and subsequent changes, within a general synchronic framework. Since etymology is an enquiry into declinationes voluntariae ('intentional derivations of words'), it concerns a precise point in time and can therefore be the object of historical scrutiny. It is noteworthy that in his synopsis of how he has arranged his contents, Varro uses the pluperfect subjunctive for the impositio verborum as opposed to the imperfect for the other two sections; note the distinction between 'perfect' and 'imperfect' status across the sentence (7.110): 'I have made (feci) three parts of the whole work On the Latin Language, first how names were set upon things (quemadmodum vocabula imposita essent rebus), second how the words are declined in cases (quemadmodum ea in casus declinarentur), third how they are combined into sentences (quemadmodum coniungerentur). ${ }^{5}$

He makes a clear distinction in Ling. 8.5-6, where he identifies duo verborum principia, namely impositio and declinatio (both derivation and declension), which provide the source and continued development of language:

The origins of words are therefore two in number, and no more: imposition (impositio) and inflection (declinatio); the one is as it were the spring, the other the brook. Men have wished that imposed nouns (impositicia nomina) should be as few as possible, that they might be able to learn them more quickly; but derivative nouns

\footnotetext{
${ }^{3}$ This famous passage is often used as evidence for the characteristics of the earliest Roman historiography: in addition to Leeman-Pinkster-Nelson 1985, ad loc., see Woodman 1988: 134-41, and 2008.

${ }^{4}$ See Taylor 2015 for a new proposal on the contents of the third part.

${ }^{5}$ The text of Ling. is from Goetz-Schoell 1910; translations derive with slight differences from Kent 1938; translations of Rust. are from Hooper-Ash 1934.
} 
(declinata) they have wished to be as numerous as possible, that all might the more easily say those nouns which they needed to use. (6) In connection with the first class (ad illud genus, quod prius), a historical narrative is necessary (historia opus est), for except by outright learning such words do not reach us (nisi discend [end] e enim aliter id non pervenit ad nos); for the other class, the second (ad reliquum genus), a grammatical treatment (ars) is necessary.

Historia here entails 'knowledge, erudite research'6 and is equivalent to empeiria, as opposed to ars or techne, but it is conceivable that this research could also be characterized as historical-archaeological or historical-cultural study. ${ }^{7}$ Varro distinguishes between linguistic uses on the diachronic level, highlighting the difference between old and new forms. The changes due to use and to the passage of time represent a difficulty for the reconstruction of the past and therefore of the original impositiones, the first forms produced by the impositio, the prisca and antica verba. Varro returns to this subject in several significant passages of the treatise, especially in the section introducing the etymological triad, and in the proem to book 7 .

Vetustas and the passing of time are among the factors that render etymological research difficult and Varro's other subjects obscuriora (cf. 5.3). It is as if the old forms are overwhelmed by the ruinae caused by the passing of time. Vetus and vetustas indicate what is 'old' (the age of a person or of an object), often in a negative sense: 5.4, vetustas pauca non depravat, multa tollit. At the beginning of both books 5 and 7, Varro compares the damage visited by time on the original linguistic heritage to the aging of man, a process that renders people unrecognizable. In book 5 the reference is to an ordinary life experience, observation of a boy's aging (5.5 'whom you saw beautiful as a boy, him you see unsightly in his old age. The third generation (tertium seculum) does not see a person such as the first generation saw him'); in the seventh the examples are drawn from literary myth: Epimenides awakens after a fifty-year sleep and is recognized by no one, and the same thing happens after fifteen years to Teucer, in the homonymous tragedy by Livius Andronicus (7.3). ${ }^{8}$ Sometimes vetustas is identified with antiquitas, and the veteres are the antiqui tout court. ${ }^{9}$ One might say that vetustas is an obstacle to etymological research, while the reconstruction of antiquitas is its objective.

Varro, however, declares himself determined to overcome the 'dark forest' caused by the ravages of time (5.5):

\footnotetext{
${ }^{6}$ Dahlmann 1940 translates it as 'Wissen', Traglia 1974 as 'ricerche storiche'. On the passage $c f$. Blank 2008: 66-67.

${ }^{7}$ One should maintain the transmitted descendendo, against the majority of editors: it would be unusual to say that the first genus, i.e., impositio, discendo pervenit ad nos. We find a modal gerund for instance in Rust. 1.1.11, quae ipse in meis fundis colendo animadverti [see Flach, ad loc.], but there the subject of gerund and perfect is the same, while here we have an impersonal gerund with genus as subject of pervenit; discere in 8.3 , recalled by Dahlmann 1940, ad loc., refers to declinatio and not impositio. Genus [...] prius and reliquum genus concern the logical and chronological priority of the impositicia nomina to the declinata and do not mean 'first class', 'second class'; descendendo indicates the several stages of linguistic transformation of the original forms. See below for other examples of descendere in similar contexts.

${ }^{8}$ Antiquarian discovery is therefore a kind of agnition; $c f$. Romano 2003: 106-07.

${ }^{9}$ Rust. 2.1 .6 veteres poetae (thus also Ling. 7.52 ); 2.1 .9 vetere instituto; 3.1 .2 vetustissimum oppidum; Ling. 5.5 verborum $[. .$.$] veterum; 9.20$ veteres leges (as opposed to the novae); the expression consuetudo vetus occurs frequently (Ling. 5.173; 6.2; 9. 13; 9.21; 10.73; cf. also usum veterem at 10.78).
} 
for there is no slight darkness in the wood where these things are to be caught, and there are no trodden paths (semitae tritae) $)^{10}$ to the place which we wish to attain, nor do there fail to be obstacles in the paths, which could hold back the hunter on his way.

The linguist may avail himself of various instruments furnished by etymological science in order to overcome these obstacles, but his research knows clear limits. The etymologist cannot hope to achieve a proper etymology of every word, but he may still be content with explaining the origin of the declinata, i.e., words which can be explained through ars, because he will thereby have explained the greater part of the lexical heritage, which consists above all in words derived from these original sources. A series of derivations may be established, and even if the origins of the earliest term remain obscure, useful work will nonetheless have been accomplished (7.4):

he who shows that equitatus 'cavalry' is from equites 'cavalrymen', equites from eques 'cavalryman', eques from equus 'horse', even though he does not give the source of the word equus, still gives several lessons and satisfies an appreciative person. ${ }^{11}$

Etymology is a formidable tool in recovering the past, and its methods embrace both historia and ars, ${ }^{12}$ but the damage caused by vetustas imposes a limit on the success of etymological enquiry.

The synchronic approach is evident in the only Varronian work that has been preserved intact, namely the De re rustica. The three books treat the rural world according to the model of peripatetic-Ciceronian dialogue: the first book discusses agriculture, the second livestock, and the third farmyard animals (which Varro defines as pastio villatica). His treatment of the material in the course of the work varies according to geographical area and population, but past and present are hardly ever distinguished. At the end of what we might consider the proem to the De re rustica (1.1), having announced that the work will be divided into three books, Varro announces that he will treat agri cultura in book 1, first separating that which does not pertain to it (namely the raising of animals, which will be the subject of books 2-3), and then following the 'natural' divisions of the material (sequens naturales divisiones). The general structure of the discussions is synchronic, but the work contains diachronic narrations as well, especially the proems, which introduce reflections on the history of culture.

An important exception to the synchronic treatment is to be found in the second book, where after the proem he extols country life as opposed to life in the city. ${ }^{13}$ At the beginning of his treatment of pastoralism (2.1.2), Varro announces that he would like to deal only with the historical part of the issue (ego vero, inquam, dicam dumtaxat quod est historicon), regarding the origo and the dignitas of res pecuaria, but that Scrofa will discuss the ars and

\footnotetext{
${ }^{10} \mathrm{Cf}$. Lucretius's Callimachean lines at $1.926-27=4.1-2$ avia Pieridum peragro loca nullius ante / trita solo.

${ }^{11} \mathrm{Cf}$. also 6.37 .

12 Taylor (2015: 25) affirms that etymology is a matter of historia and it is not an ars: the lost triad of Ling. 2-4 discussed the nature of ars and the usefulness of the disciplina verborum originis, but it seems to me more probable that Varro concluded that both methods should be used in combination.

${ }^{13}$ On the subject $c f$. also Rust. 3.1.4, neque solum antiquior cultura agri, sed etiam melior, and 2. pref. 1 viri magni nostri maiores non sine causa praeponebant rusticos Romanos urbanis (the entire proem to book 2 is a moralistic exaltation of country life over city life).
} 
scientia pastoralis. There is no doubt here that historicon has to do with the very informed description of aspects that are related to history, in a well-attested sense of historia as knowledge based on sound experience and reliable sources, and so the adverb historicos could refer to an accurate and informed treatment. ${ }^{14}$ Varro, indeed, treats the origo of pastoralism in paragraphs 3-5, and dignitas in 6-10. He offers an overview of the origo, adopted from Dicaearchus of Messana, who distinguished three successive stages in human history, a history in which human beings and animals always existed, regardless of the issue of principium that philosophers discuss (2.1.3-5= Dicaearchus fr. $48 \mathrm{~W}$. = fr. $54 \mathrm{M}$.):

As it is a necessity of nature that people and flocks have always existed (whether there was an original generating principle of animals, as Thales of Miletus and Zeno of Citium thought, or, on the contrary, as was the view of Pythagoras of Samos and of Aristotle of Stagira, that there was no point of beginning for them), it is a necessity that from the remotest antiquity of human life they have come down, step by step to our age (necesse est humanae vitae ab summa memoria gradatim descendisse ad hanc aetatem), as Dicaearchus teaches, and that the most distant stage (summum gradum) was that state of nature in which man lived on those products which the virgin earth brought forth of her own accord; (4) they descended from this stage into the second, the pastoral (ex hac vita in secundam descendisse pastoriciam), in which they gathered for their use acorns, arbutus berries, mulberries, and other fruits by plucking them from wild and uncultivated trees and bushes, and likewise caught, shut up, and tamed such wild animals as they could for the like advantage [...] (5) Then by a third stage man came from the pastoral life to that of the tiller of the soil (tertio denique gradu a vita pastorali ad agri culturam descenderunt); in this they retained much of the former two stages, and after reaching it they went far before reaching our stage. Even now (etiam nunc) there are several species of wild animals in various places.

Varro thus gives us a natural summus gradus, during which humans lived off wild foods from nature, then a second pastoral stage, followed by a third agricultural stage. The third stage, Varro explains, develops from the previous two, ${ }^{15}$ and retains many of their characteristics, in addition to developing further until the present day. One might wonder whether he views the present as a fourth stage, but it seems to me more likely that his words must be interpreted as a contrast between the 'earlier' and the 'now', with the 'earlier' being tripartite (he seems to mark a break with etiam nunc). ${ }^{16}$ The binary opposition between city and country life belongs on a different level, since it concerns space rather than time, even though it has a clear temporal dimension in that country life came before city life $(3.1-4$, esp. 1):

\footnotetext{
${ }^{14}$ Cf. Rust. 3.16.3 'Merula ['Blackbird', who deals with bird breeding!], as he has done in other cases, presents a learned treatment (historicos) also for beekeepers'. For the rare adverb historicos (= i $\sigma \tau$ 16-19 ('fere i.q. secundum rationem eorum quae experientia inventa sunt'). For this sense of historia, cf. Varro Sat. Men. 414 (historiam necessariam, and cf. Cèbe 1994: 1737); Dicaearch. fr. 49, 30-31 Wehrli = 56A, 43-44 Mirhady 'these things [...] are not asserted by us, but by those who have spoken after researching thoroughly

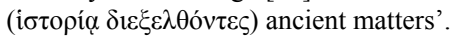

${ }^{15}$ Cf. also Rust. 1.2.16 (= Dicaearch. fr. 51 W. $=55$ M.) 'You may even add this that the shepherd's life is the treble (incentivam), and the farmer's plays the accompaniment (succentivam), if we may trust that most learned man, Dicaearchus', and 2. pref. 4.

${ }^{16}$ For an analysis of Varro's history of civilization which proposes a different conclusion on the present age as a 'fourth stage' in Dicaearchan terms, see Nelsestuen, section 3, in this volume.
} 
Though there are traditionally two ways in which men live (cum duae vitae traditae sint hominum [note the use of vitae as in 2.1.3]) - one in the country, the other in the city $[\ldots]$ there is no doubt that these differ not merely in the matter of place, but also in the time at which each had its beginning.

While the city/country binary is not to be confused with Dicaearchus's model of the three phases of human history, there is some overlap between the two in that the transition from rural to urban life coincides, at least in Rome, with the transition from Dicaearchus's second to third phases. In fact, the founders of Rome learned the cultivation of the fields from their shepherd ancestors (2. pr. 4), ${ }^{17}$ even though Romulus and Remus were shepherds themselves (2.1.9).

The second point that Varro had promised (2.1.2) to discuss after origins of pastoralism — that of dignitas - is also treated historically, possibly with some dependence on Dicaearchus, and with a focus on cultural matters. He begins by stating that 'of the ancients the most illustrious were all shepherds, as appears in both Greek and Latin literature, and in the ancient poets' (2.1.6). This lays the basis for valorizing the origins of Rome, since Romulus and Remus were shepherds (2.1.9-10). There is an undercurrent of moralistic exaltation of rural as opposed to city life, but it is also clear that Varro embraces the idea of human progress. Agriculture represents an improvement upon previous stages, not a decline; this may mark a departure from Dicaearchus, but there is in fact much debate about Dicaearchus's moral evaluation of the development. ${ }^{18}$ In Varro, the passing from the natural to the agricultural phase is certainly seen as undeniable technical progress. On the other hand, there is more than a touch of decadence about the transition from rural to urban living. This transition probably took place during the third (agricultural) phase, or perhaps in the lead-up to the present day; accordingly, it is to be located either squarely within the third phase or beyond the entire schema.

Varro's tendency to systematic organization leads him to reflect on the category of tempus and to stratify it comprehensively into layers. Another general historical schema that reveals Varro's view on human history and the history of culture is to be found in a fragment preserved by Censorinus (De die natali 21.1-2 = Varro De gente pop. Rom. fr. 1 Fraccaro $=$ Ant. hum. lib. XIX fr. I Mirsch) $:{ }^{19}$

I will now speak of that period which Varro calls historic (quod historicon Varro appellat). This author divides time into three periods: the first extends from the origin of man to the first cataclysm, and he calls it uncertain (adelon), on account of the obscurity in which it is concealed (propter ignorantiam). The second extends from the first cataclysm to the first Olympiad and as it has given rise to numerous fables (quia multa in eo fabulosa referuntur) he calls it mythological (mythicon).

\footnotetext{
${ }^{17}$ Flach (1997: 181-82) is correct that qui condiderunt urbem is an expansion of the immediately preceding progeniem suam, rather than having the earlier pastores as its antecedent; the following progenies eorum refers to the relative sentence, qui condiderunt urbem, rather than to the preceding progeniem suam.

${ }^{18}$ Cf. Fraccaro 1907: 115; Della Corte 1976: 129-30; Ax 2000: 345-46; Saunders 2001; Schütrumpf 2001; Feeney 2007: 113; Baier 2007: 262-64; McConnell 2014: 134-35; $c f$. also Nelsestuen 2011: 340-41. The key issue is how to reconstruct Dicaearchus's opinion on the basis of frs 48 and $49 \mathrm{~W}$ (= 54 and 56A M.). Even in the history of language, the passage of time does not necessarily imply only damage and devastation; the consuetudo loquendi may also include improvements: $c$. Ling. 9.17. Varro would have had a cyclical concept of history according to Deschamps (1987, in particular 189).

${ }^{19}$ On the fr. see most recently Cole 2004: 419-22; Möller 2005: 255-58 (with previous bibliography), and Feeney 2007: 77-82.
} 
The third extends from the first Olympiad to our time. He calls this historic (historicon), because the events which transpired during this interval are related in reliable histories (quia res in eo gestae veris historiis continentur).$^{20}$ (2) As to the first period, whether or not it had a commencement, it is certainly impossible to establish how many years it comprised. As to the second, we cannot say exactly, but we may believe that it covered about one thousand six hundred years. From the first cataclysm, which is called that of Ogyges, until the reign of Inachus about four hundred years are counted [...] from that time until the first Olympiad, a little more than four hundred are counted. And as solely these events, although belonging to the end of the mythical period, approach the age of historians, several writers have attempted to give the number more exactly.

Censorinus has just stated that if he had known the origo mundi, he would have begun there (20.12). He will treat instead the time period that Varro called historicon, reporting Varro's distinguished tria discrimina temporum, their etymologies, and the rationale for the division. Censorinus specifies the duration of these time periods. The beginning of the first is uncertain, because it is not known whether there was a beginning at all or whether the world has always existed ( $c f$. above Rust. 2.1.3, where Varro states decisively that life is eternal, et homines et pecudes cum semper fuisse sit necesse natura, and also Sat. Men. 84 and 268). ${ }^{21}$ Due to this uncertainty, the first period is not of an identifiable duration. The second lasted about 1600 years until the first Olympiad at $776 \mathrm{BC}$ (there are doubts about the text that would indicate further subdivisions of 400 or 800 years). It is worth noting that the final 400 years of the mythical period could be better known than its earlier years, since those later years are closer in time to the era of the writers (a memoria scriptorum proximos). Censorinus afterwards tells us in reference to the third historical period that Varro studied in depth the chronology and synchrony of various civitates, eliminating 'all confusion around the issue and caused the light of truth to emerge' (21.5), probably alluding to a series of astronomical calculations, the curiosae computationes that Arnobius informs us were contained in the first book of the De gente populi Romani. ${ }^{22}$ The provenance of this testimonium of Varro by Censorinus is uncertain, but in fact it is very likely to have come from De gente populi Romani and not from the Antiquitates as argued by Mirsch. ${ }^{23}$ The schema is undoubtedly of Greek origin. ${ }^{24}$

\footnotetext{
${ }^{20}$ The verae historiae are opposed to fabulares poetarum historiae at 4.6 (cf. also 17.3); on this opposition $c f$.

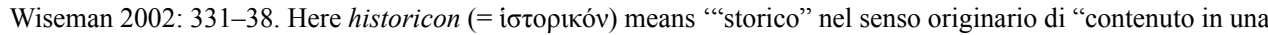

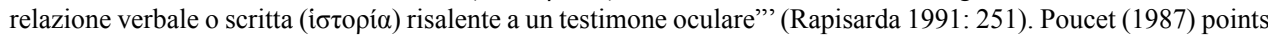
out the singularity of this threefold partition of past time in the Roman historical and literary tradition.

${ }^{21}$ Sat. Men. 84: Varro autem in satura quae scribitur de salute ait mundum haud natum esse neque mori; 268: nec natus est nec morietur: viget, veget, utpote plurimum. The philosophical genus of theology (see below) dealt also with the question a quodam tempore an a sempiterno fuerint dii (Ant. div. fr. 8 Cardauns; $c f$. also fr. 88).

${ }^{22}$ Arn. Adv. nat. 5.8 .7 (= Varro gpR fr. 20); on this counting see Grafton-Swerdlow 1985: 456; 1986: 149. It would seem that Cicero is referring precisely to this fact in the famous laus Varronis in the Academica (1.9): $t u$ descriptiones temporum [...] aperuisti.

${ }^{23}$ Cf. Rocca-Serra 1980: 66. Franceschi 1954: 411-12 thinks the testimonium derives from the Antiquitates.

${ }^{24}$ It could derive from the same Dicaearchus of whom we have only a few fragments. I would point to the use of

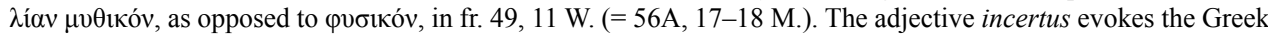
sceptic tradition: cf. Varro Log. 77 (= August. De civ. D. 29.1.3): ob hoc distinguit ab Academicis novis, quibus

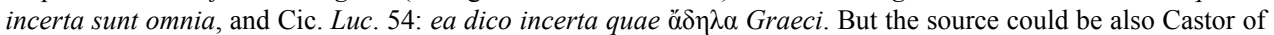
Rhodes (cf. Ax 2000: 359 and n. 64, with previous bibliography) or Eratosthenes (thus most recently Feeney 2007: 147 n. 92).
} 
There is some similarity with the terminology of Varro's 'tripartite theology', with the tria genera theologiae, namely mythicon or fabulare, physicon or naturale, and civile, ${ }^{25}$ especially with the mythical theology, used in particular by the poets. The three theological genera do not receive a chronological treatment but rather concern the ratio quae de diis explicatur (Ant. div. 7) and something similar could be said about the three periods of humanity, characterized by the reliability of the information we receive about them (uncertain, fictitious, true) and not by their era, even if their level of reliability is essentially a consequence of the times in which they occur; it is, after all, possible that Varro had in mind a logical and therefore chronological arrangement of the three genera theologiae also. The degree of 'historicity' of an era depends not only on the possibility to narrate it by reliable stories, but also to frame it with a certain chronological scheme. ${ }^{26}$

And, indeed, Varro, in describing in the De gente populi Romani the process that culminated in the birth of the Roman people, does not attempt to go back beyond the limit of the adelon time, the flood of Ogyges, 'and does not propose to himself, as the starting point from which he may arrive at Roman affairs, anything more ancient than the flood of Ogyges, that is, which happened in the time of Ogyges' (fr. 3 = August. De civ. D. 18.8). The same limit is used as a terminus ante quem for dating the foundation of Thebes, the beginning of urban life in Greece (Rust. 3.1.1), but it is impossible to calculate when rural life actually began, and so Varro merely states that the two events are separated 'by an immense number of years' (immani numero annorum).

From what we have seen so far in our survey of Varro's treatment of the past, it emerges he exhibits the same methodological approach in the reconstruction of the past both when he has to return to the most ancient events and when he must find traces of ancient institutions and customs by means of etymological inquiry. In both cases, Varro endeavours to reconstruct the origo of a word (Ling. 5.7 nunc singulorum verborum origines expediam), or of an institution (for instance, pastoralism), but also of the human race. The origo is shrouded in uncertainty, and uncertainty, as we have seen, is a characteristic of the most ancient era, adelon, which Varro has no hope of being able to reconstruct. We have seen that in the case of etymology the genealogical-reconstructive method cannot always access the ultimate origo, the original impositio (Ling. 7.2 tamen latent multa; 4 non omnium verborum posse dici causa $<m>$ ). Unlike the Stoics, Varro does not believe that the origin of words is always identifiable. He also departed from Stoic thinking on human history, which posited a beginning, following instead Aristotle and the Pythagoreans (Rust. 2.1.3): if the beginning is lost in infinity, it is more understandable that it cannot be chronologically fixed.

The etymological method involves reconstructing in a backward direction the successive stages of linguistic development. The proem to book 7 of Ling. is particularly instructive, where the metaphor of the tree and its roots is especially relevant for etymological reconstruction (7.4):

\footnotetext{
${ }^{25}$ See August. De civ. D. 6.5 (= Varro Ant. div. 7 C.): tria genera theologiae dicit esse [...] eorumque unum mythicon <appellari>, alterum physicon, tertium civile, i.e., with Latin words, fabulare or fabulosum, naturale, civile (see also frs 8-10 C). On the three branches of theology see also MacRae, p. XXX and Hadas, p. XXX in this volume.

${ }^{26}$ The temporal category of adelon facilitates an approach to mythical and historical periods on the basis of these two criteria (Hoces Sánchez 2012: 156).
} 
If I have no knowledge of the roots (radices) of a tree, still I am not prevented from saying that a pear is from a branch, the branch is from a tree, and the tree from roots which I do not see.

Just as one can work back from the fruit to the roots, which cannot be seen and so must be assumed, so too one can trace back from the final linguistic derivation to the first impositio; and even if one reaches the end of the line, that in itself is a considerable achievement (see also above, p. XXX). There is a significant epistemological similarity here with what we saw regarding the tria tempora of human history, especially as regards the limits upon historical reconstruction as it is pursued backwards. This method allows Varro to reconstruct the chronology of astronomical events, 'counting backwards the eclipses' (Censorinus 21.5). In the passage of Ling. he clearly states that one who does not know the roots is not thereby prevented from deducing the subsequent derivations: the ultimate goal is always the origo, but the subsequent steps of the process under examination are also relevant.

A significant affinity therefore seems to emerge between etymological research and the historical study of origins. The object of the study is the same, namely antiquitas and origo, attained through the genealogical-reconstructive method. ${ }^{27}$ The events under investigation can then also be chronologically narrated by reversing the backwards order of the research into a normal chronological order of presentation, as in the case of the De gente populi Romani $^{28}$ or of the history of the res pecuaria at Rust. 2.1.2; but in Varro, the systematic arrangement of the results of his researches on the basis of general categories, the naturales divisiones mentioned in Rust., seems to be more frequent.

Another example of the affinity between specific etymological analysis and more general study of the past emerges from several significant lexical similarities between more general passages from his treatises. I am referring to the image of the gradus descendere which indicates the successive stages of a general developing process. Gradus descendere means descending a flight of stairs. ${ }^{29}$ The gradual progression is typical of the logical reasoning in dialectics, ${ }^{30}$ but also in rhetoric, where the gradatio is the climax, or epiploke, in which the various elements are linked as in a chain. ${ }^{31}$ Varro utilizes this image in several passages to indicate the sequence of logical and also chronological steps, which are distinct but contiguous. As we have seen at Rust. 2.1 regarding the various stages of human civilization, the humanae vitae gradually succeeded one another up until the present moment (necesse

${ }^{27}$ Cf. Romano 2003: 114-17. On the epistemological status of Varro's etymology and its ultimate antiquary and historical goal see Blank 2008: esp. 68.

${ }^{28}$ Narrative and probably organizational traces, mainly diachronic ones, are to be found in the De gente populi Romani ( $c f$. in part frs 3 and 8 ) and (a little more doubtfully) in the De vita populi Romani, where Riposati 1939: 257-58 and now Pittà 2015: 12 and 61-66 argues for a general chronological arrangement.

${ }^{29}$ Cf. Plin. HN 36.88: porticusque descenduntur nonagenis gradibus; Ovid has stairs in mind at Fast. 6.397-98: huc (i.e. Nova Via) pede matronam nudo descendere vidi (perhaps because he uses gradus in the following verse: obstipui tacitus sustinuique gradum); not literal: Varro Rust. 3.11.1: naturalis aut lacus aut stagnum aut manu facta piscina, quo gradatim descendere possint (but the otherwise related Columella, Rust. 8.15.3 may be a literal use).

${ }^{30}$ See in particular Cic. Nat. D. 1.89, who clearly distinguishes descendere from praecipitare.

${ }^{31}$ Rhet. Her. 4.34: 'Climax is the figure in which the speaker passes (descendit) to the following word only after advancing by steps to the preceding one (ad superius ascensum est)'; cf. Quint. Inst. 9.3.54 and 9.4.28 (on amplificatio and deminutio); Isid. Etym. 2.21.4. On gradatio see Lausberg 1990: $\S 623,315-17$; WisseWinterbottom-Fantham 2008: 324. 
est humanae vitae ab summa memoria gradatim descendisse ad hanc aetatem), the summus gradus being natural. From this state, the following pastoralist one is derived (ex hac vita in secundam descendisse pastoriciam). In the third stage (tertio denique gradu), men moved from pastoralism to agriculture (ad agri culturam descenderunt), a phase that maintained many of the previous circumstances and from which they arrived finally at the current state (in qua ex duobus gradibus superioribus retinuerunt multa, et quo descenderant, ibi processerunt longe, dum ad nos perveniret). Still referring to Dicaearchus's opinion on the movement between the various stages, Varro uses the term gradus to indicate that people mastered agriculture only in a later phase (1.2.16: inferiore gradu aetatis susceptam agri culturam [sc. ab hominibus]: see above n. 15).

It may be instructive to compare these passages with the well-known - but difficult — passage in the De lingua Latina where he speaks of the four gradus etymologiae (Ling. 5.7-9):

Now I shall set forth the origins of the individual words (singulorum verborum origines), of which there are four levels of explanation (quattuor explanandi gradus). The lowest (infimus) is that to which even the common folk has come (venit); who does not see the sources of argentifodinae 'silver-mines' and of viocurus 'roadoverseer'? The second is that to which old-fashioned grammar has come (quo grammatica descendit antiqua), which shows how the poet has made (finxerit) each word, how he has composed (confinxerit) each word, and how he has derived (declinarit) each word. Here belongs Pacuvius's rudentum sibilus 'the whistling of the ropes', here his incurvicervicum pecus 'incurvate-necked flock', here his clamide clupeat brachium 'with his mantle he beshields his arm'. (8) The third level is that to which philosophy ascended (ascendens pervenit), and on arrival began to reveal the nature of those words which are in common use, as, for example, from what oppidum 'town' was named, and vicus 'row of houses', and via 'street'. The fourth is that where the sanctuary is, and the mysteries †of the king $\dagger$ (adytum et initia $\dagger$ regis $\dagger$ ): if I shall not arrive there (quo si non perveniam) *** at full knowledge (scientiam), ${ }^{32}$ at any rate I shall cast about for a conjecture (opinionem), which even in matters of our health the physician sometimes does when we are ill. (9) But if I have not reached the highest level (summum gradum), I shall nonetheless go farther up (praeteribo) than the second, because I have studied not only by the lamp of Aristophanes, but also by that of Cleanthes. I have desired to go farther (praeterire) than those who expound only how the words of the poets are made up. For it did not seem appropriate that I seek the source in the case of the word which Ennius had made, and neglect that which long before King Latinus had made, in view of the fact that I get pleasure rather than utility from many words of the poets, and more utility than pleasure from the ancient words. And in fact are not those words mine which have come to me by inheritance from King Romulus, rather than those which were left behind by the poet Livius?

Varro maintains that there are quattuor explanandi gradus of the origines singulorum verborum. The infimus, quo populus etiam venit, offers an explanation of simple compounds. The second, quo grammatica descendit antiqua, deals with words created by the poets. The third instance is that of philosophy, that is, the philosophical tradition that has concerned

${ }^{32}$ It would seem necessary to fill the supposed lacuna before scientiam with a negation and a verb governing the noun. 
itself with the science of language, such as, above all, the Stoic tradition, which mostly treats commonly used words. The fourth instance is mysterious and the formulation referring to it is very difficult. Varro wants to go over the methods of the second instance of ancient grammar, in a sort of reconciliation between Alexandrian grammar and Stoic philosophy (quod non solum ad Aristophanis lucernam, sed etiam ad Cleant $<h>$ is lucubravi). He also wants to discuss commonly used words. It would not make sense to seek the origin of the words used by Ennius and to disregard those by the ancient King Latinus, since poetic words are the sources of voluptas, common words of utilitas (cum poeticis multis verbis magis delecter quam utar, antiquis magis utar quam delecter). The words inherited from Romulus do not belong to the linguistic heritage any less than those handed down by the poet Livius Andronicus.

The passage has been studied assiduously, and we cannot examine here all the details and problems related to it. ${ }^{33} \mathrm{I}$ do, however, believe that the term gradus is pertinent to our discussion, as are the verbs indicating movement (venire, pervenire, praeterire), especially descendere (secundus (sc. gradus) quo grammatica descendit antiqua) and ascendere (tertius gradus, quo philosophia ascendens pervenit). It seems clear to me that the overall scheme is essentially the same as that of the progression of the vitae humanae in the Rust., with subsequent and contiguous gradus (each following gradus presupposes the previous one and is, in a manner of speaking, its product, just as it, in turn, is the prerequisite of the next one). The order is progressive and thus chronological: ancient grammar precedes philosophy. The resulting chronology is not connected with the age of the material being studied (the common lexicon, poetic language), but with the methods, the ratio, used to study it (the grammatica antiqua assumes the existence of a 'modern' counterpart).

If we compare this section with that in the Rust. (about ten years later), we also see how the descendit referring to the second instance of the etymology does not imply any inferiority vis-à-vis the previous stage. This verb is used also in the case of the humanae vitae (see above, p. XXX) and merely indicates a progression. ${ }^{34}$ The word does therefore not require emendation, as some have suggested. ${ }^{35} \mathrm{It}$ is, however, true that the process runs from infimus to summus gradus and therefore describes not only the succession of methods but also their progress (as in the humanae vitae). Along these lines, ascendens, which characterizes philosophy, seems to connote progress in the leap forward from Alexandrian grammar to Stoic philosophy. Here Varro uses a reversed version of the chronologicalprogressive model of Rust. 2.1, where the summus gradus is the most ancient and natural, ${ }^{36}$ with a more marked sense of progress. The summus gradus in Ling. is indeed the fourth, while the infimus is the opening and most basic one. One might conclude either that in the model of rustic life there was after all some residual basic idea of a decline vis-à-vis antiquity, or, what I think is more probable, that the four etymological instances point towards the future, and in particular towards Varro's own treatise, allowing for the possibility of further

\footnotetext{
${ }^{33}$ See Piras 1998: 57-71 and 2015: 53-57 and Blank 2008: 69-71; on gradus and descendere see also Nelsestuen, p. $\mathrm{xxx}$, in this volume.

${ }^{34}$ On the value of descendere in Rust. 2.1.3-5 cf. Cardauns 2001: 22: 'descendisse [...] ist hier nicht im Sinne einer moralischen Deszendenztheorie gebraucht, die Varro hier fernliegt, sondern neutral'; Saunders 2001: 243 n. 8 ('purely chronological'); Schütrumpf 2001: 257-58 and n. 13. See also Nelsestuen in this volume, p. XXX.

${ }^{35}$ Escendit Schioppius (Caspar Schoppe 1602), adopted by Kent 1938 and Collart 1954; Andreas Spengel proposed ascendit.

${ }^{36}$ Schütrumpf 2001: 258 n. 13, notes the uncommon usage of summus here, usually indicating the 'letzte Stufe', and suspects it originates from the image of 'Abstieg' (descendisse).
} 
progress (quo si non perveniam [...] opinionem aucupabor [...] quodsi summum gradum non attigero, tamen secundum praeteribo). In Rust., on the other hand, Varro seems more interested in the process which began in the very distant past (summa memoria) and has in view no stage later than the contemporary status quo. As in Rust., the stages of development can be divided into two main sections: a threefold division of the past, and a present, with the implied possibility of a future.

The examples in paragraph nine on the creators of poetic and common language give rise to further reflections on Varro's attitude to the past. ${ }^{37}$ Ennius is the poet most often cited in the Ling., which can be explained by the high regard that Varro had for the national Roman poet of the late Republic. He is compared with rex Latinus, a king before the rise of Rome, the first king of the Latins: ${ }^{38}$ 'For it did not seem appropriate that I should seek the source of a word which Ennius had made, and neglect that which long before King Latinus had made.' After the antithesis between voluptas and utilitas (cum poeticis multis verbis magis delecter quam utar, antiquis magis utar quam delecter), which is quite frequent in Varro ( $c f$. Baier 2007), the poet/king opposition is repeated in a chiasmus in the rhetorical question which follows. Romulus qua name-giver and Livius Andronicus stand for common and poetic language respectively ('and in fact are not those words mine which have come to me by inheritance from King Romulus, rather than those which were left behind by the poet Livius?'). In the first pair (Ennius/Latinus), the antithesis also has a temporal dimension: ante rex Latinus [...] cum [...] verbis [...] antiquis. Rex Latinus also represents antiquitas relative to Ennius. Certainly Varro was aware of the significant time gap between Romulus and Livius Andronicus, but the gap between Latinus and Ennius was even more significant, since Latinus dates from before Romulus and the founding of Rome. The founding coincided almost exactly with the first Olympiad on the cusp of the mythical and historical eras, as we pass from Latinus's era in which multa fabulosa referuntur to that in which res gestae veris historiis continentur. It is notable that Latinus belongs to the last part of the mythical era, which it is not completely impossible to reconstruct ( $c f$. p. XXX above, and Censorinus 21.2).

This contrast also falls within another trend that has been observed in Varro, namely that of using the concept of antiquitas in a relative way, without an exact chronological specification. ${ }^{39}$ Latinus, and perhaps also Romulus, are antiqui when compared with Ennius and Livius Andronicus, as well as with Varro himself. The contrast between past and present is indeed ubiquitous in Varro, but in several passages one may also note a threefold temporal gradation, namely antiquissimum/antiquum/nunc, a distinction between the remote past, the near past, and the present. Thus, e.g., in Ling. 7.3, where there is a discussion of the antiquity of poetic words, it is said that the Carmina Saliorum, the first attestation of verba poetica latina, date back seven hundred years to the era of Numa, unless they are from an even earlier age (neque ea ab superioribus accepta). So here too there is the distinction between past and remote past, and an attempt at precise dating to Numa's reign is only made in the historical era, in the case of the origin of the Carmina Saliorum.

Immediately thereafter Varro adds that in the reconstruction of the past one might

\footnotetext{
${ }^{37}$ Cf. Piras 2015: 56-57.

${ }^{38} C f$. $g p R$, fr. 29 'Troy was overthrown [...] And this was done in the reign of Latinus the son of Faunus, from whom the kingdom began to be called Latium instead of Laurentum.'

${ }^{39}$ Romano 2003: 112-13. Cf., e.g. Ant. hum. 17.1 'Varro thought that the Romans borrowed the names of their months from the Latins. He demonstrated in quite a plausible manner that these names are older (antiquiores) than the city of Rome.'
} 
reproach someone who cannot identify the atavus ('great-grandfather's grandfather') or tritavus ('great-great-grandfather's grandfather') of a hero. But such a reproach would be unjust, since even in regular life it is often the case that one cannot determine the mother of one's tritavus, and 'this interval is much closer to us than the stretch from the present time to the beginning of the Salians, when, they say, the first poetic words of the Romans were composed in Latin'. In this case as well we have comparison between present (the writer, the interlocutor) and past (the hero on the one hand and the tritavus on the other) and remote past (the hero's distant ancestors or the female ancestor of the tritavus, who is even more difficult to trace because of the complexities of the Roman genealogical system).

We have already seen (p. XXX) in the proem to book 5 the difficulties in recognition caused by a gap of two generations, tertium seculum non videt eum hominem quem vidit primum. In the same passage it is said that even maiores, the Romans of several generations previously, had in their turn a remote past which was hard to access and reconstruct, 'those things that oblivion has snatched away even from our ancestors, the painstaking labours of Mucius and Brutus, although they have pursued the runaways, cannot bring back' (5.5). ${ }^{40}$ The Romans who were already ancient from Varro's standpoint in fact lived closer to the boundary between myth and history. On this basis, the examples in Ling. of a tripartite division of time across present, past, and remote past, seems coherent in its own right, and comparable (while not coinciding precisely) with models of time in the other treatises which we have discussed, from the tria discrimina temporum as reported by Censorinus to the three stages of human history borrowed from Dicaearchus. For Varro, uncertainty about the ultimate origo and progression by successive stages are features of the past which need to be explored through a genealogical-reconstructive method. This method is oriented backwards and substantially inductive, based on specific traces and clues, often the testimonies of the veteres, in particular the poets, even though these testimonies are not always completely reliable. The research and the reconstruction proceed step by step, determining events and data (synchronism, eras, forms or significances of words) with the goal of extracting as far as possible what is 'buried by the lapse of time' (Ling. 6.2), but always with awareness of the difficulties of getting beyond what veriis historiis continentur.

Sapienza, University of Rome

${ }^{40}$ Note that Mucius is Mucius Scaevola I, mentioned in De oratore as promoter of the collection of Annales Maximi, and Brutus is the jurist Iunius Brutus, also mentioned in De oratore (and see above, p. XXX). 